\title{
Analisis Persepsi Nilai, Kepedulian Keamanan Pangan dan Kesadaran Kesehatan yang Memengaruhi Keinginan Membeli Pangan Organik (Studi Kasus Mahasiswa S1 Institut Pertanian Bogor)
}

\author{
Bungaran Raymond Titus \\ Departemen Manajemen, Fakultas Ekonomi dan Manajemen, \\ Institut Pertanian Bogor \\ Kampus Dramaga Bogor 16680 \\ Musa Hubeis \\ Departemen Manajemen, Fakultas Ekonomi dan Manajemen, \\ Institut Pertanian Bogor \\ Kampus Dramaga Bogor 16680 \\ e-mail: hubeis.musa@yahoo.com
}

\begin{abstract}
In the beginning of $21^{\text {st }}$ century, the healthy life style of the modern society has been increasing, indicated by the increased consumption of organic food. Organic food is kind of food produced without chemical materials nor pesticide. The research attempts to analyze the influence of health consiousness, perceived values, and food safety concern toward the intention of purchasing organic food. The population were IPB undergraduate students and the sampling techniques used were Slovin and Quota. This research used multiple linear regression as its analysis method, supported by Statistical Product and Service Solutions (SPSS for windows versi 16.0). The result showed that partially there was positive influence of perceived values and health conciousness toward intention for purchasing organic food; however, food safety concern did not have any influence towards intention for the purchase. Simultaneously, there was positive influence of perceived values, food safety concern and health conciousness towards intention for purchasing.

Keywords: perceived values, food safety concern, health consciousness, organic food, purchase intention
\end{abstract}

\begin{abstract}
ABSTRAK
Memasuki abad 21, kecendrungan gaya hidup sehat di kalangan masyarakat modern semakin meningkat dengan mengkonsumsi pangan organik dalam arti umum (sayur, beras, dan sejenisnya). Pangan organik adalah pangan yang diproduksi tanpa pupuk kimia atau pestisida. Tujuan penelitian adalah menganalisis pengaruh kesadaran kesehatan, persepsi nilai dan kepeduliaan keamanan pangan terhadap keinginan membeli pangan organik. Penelitian dilakukan terhadap sivitas IPB strata 1 dan teknik pengambilan contoh dengan Teknik Slovin dan Kuota. Metode analisis yang digunakan adalah regresi linear berganda dengan Statistical Product and Service Solutions (SPSS for windows versi 16.0). Hasil penelitian menunjukan secara parsial terdapat pengaruh positif persepsi nilai tentang pangan organik dan kesadaran kesehatan terhadap keinginan membeli produk pangan organik, di samping pengaruh negatif kepedulian keamanan pangan dengan keinginan membeli pangan organik. Secara simultan, terdapat pengaruh positif persepsi nilai tentang pangan organik, kepedulian pada keamanan pangan dan kesadaran kesehatan terhadap keinginan membeli pangan organik.

Kata kunci: keinginan membeli, kepedulian keamanan pangan, kesadaran kesehatan, pangan organik, persepsi nilai
\end{abstract}




\section{Pendahuluan}

Memasuki abad 21, kecenderungan gaya hidup sehat di kalangan masyarakat modern semakin meningkat. Pola hidup sehat menjadi salah satu ukuran standar mutu. Kecendrungan hidup sehat mulai muncul di kalangan sebagian masyarakat di tengah kepadatan aktivitasnya. Di Indonesia, salah satu dari sekian usaha untuk kembali hidup sehat juga telah dilakukan termasuk dengan memperkenalkan pangan organik. Secara umum pangan organik merupakan pangan yang mempunyai standar kesehatan yang direkomendasikan. Dalam beberapa dekade terakhir telah terjadi peningkatan dalam produksi dan konsumsi pangan yang diproduksi secara organik.

Pangan organik bisa menurunkan tingkat depresi. Penelitian terakhir yang dikeluarkan oleh berita pers di Inggris menyimpulkan bahwa banyak penyakit mental belakangan ini disebabkan oleh pangan yang dikonsumsi. Orang perlu untuk mengkonsumsi pangan organik untuk membantu mengurangi gejala depresi. Pertanian organik telah diterapkan hampir di sebagian besar negara di dunia. Di seluruh dunia, total area yang digunakan untuk pertanian organik telah tercatat lebih dari 24 juta hektar. Lahan pertanian organik terluas berada di Australia (10,5 juta ha), Argentina (3,2 juta ha) dan Italia (1,2 juta ha). Sementara di wilayah Asia, negara dengan lahan pertanian organik terluas adalah India dan China (Thio et al. 2008).

Dalam hubungannya dengan pertumbuhan permintaan potensial, beberapa penelitian telah mengidentifikasi motivasi konsumen dalam membeli pangan organik dan secara umum telah memperlihatkan gambaran positif terhadap kuatnya permintaan. Saat ini telah terjadi peningkatan permintaan konsumen untuk produkproduk pertanian yang dihasilkan dengan proses ramah terhadap lingkungan, khususnya yang dihasilkan secara organik. Walaupun permintaan pasar akan pangan organik masih terbilang kecil, terdapat tanda-tanda bahwa pasar peminat pangan organik semakin dewasa dan berkembang dibandingkan beberapa tahun sebelumnya.

Agung Prowoto dan Lasti Kurnia dikutip oleh Parlyna dan Munawaroh (2011) juga menyebutkan bahwa permintaan konsumen terhadap pangan organik terus meningkat. Pangsa pasar dunia dari produk organik dalam 10 tahun ke depan akan mencapai sekitar 100 milyar dollar AS. Amerika Serikat dan Jerman adalah negaranegara yang tingkat konsumsi pangan organiknya sangat tinggi. Parlyna dan Munawaroh (2011) menyebutkan perkembangan pasar pangan organik di Amerika Serikat (AS) sejak 1990 sekitar 20\% setiap tahunnya. The World of Organic Agriculture 2011 menguraikan bahwa pasar domestik pangan organik terbesar tahun 2009 adalah Amerika Serikat dengan nilai 17,835 milyar Euro, disusul oleh Jerman 5,800 milyar Euro dan Perancis 3,041 milyar Euro.

Pasar utama produk organik negara-negara berkembang Asia masih negaranegara maju, tetapi pasar dalam negeri juga sudah mulai berkembang semakin kuat walaupun relatif masih kecil. Di Oseania, termasuk di Australia dan Selandia Baru, pertumbuhan kuat produksi pangan organik sangat dipengaruhi oleh permintaan ekspor, walaupun pasar dalam negeri juga bertumbuh. Di Amerika Latin, produk organik utama adalah buah-buahan tropis, biji-bijian, serealia, kopi dan kakao. Di Indonesia, khusus-nya di daerah Bogor, Jawa Barat, menurut penelitian Alamsyah (2010), permintaan produk organik terutama sayuran terus meningkat, yang ditunjukkan oleh data penjualan sayuran organik di supermarket Giant Taman Yasmin. 
Dari November 2009 sampai Januari 2010 penjualan meningkat dari Rp8.475.898,00 menjadi Rp12.673.161,00 (Hubeis et al. 2013).

Pembelian makanan organik di Indonesia masih tergolong rendah. Hasil survey penelitian YLKI (2012) dengan 609 responden beberapa wilayah di Jakarta menunjukan konsumen yang mengonsumsi beras organik $24 \%$, mengkonsumsi buah-buahan $17 \%$, dan dalam bentuk bumbu-bumbu $3 \%$. Konsumen tidak membeli makanan organik dengan alasan di antaranya harga yang mahal, keterjangkauan, dan akses tempat yang masih sangat sulit. Sementara 34\% lainnya (205 orang) tidak mengetahui tentang pangan organik (Wijaya 2013).

Selanjutnya, apakah benar dengan mengkonsumsi pangan organik dapat meningkatkan kesehatan konsumen? Beberapa alasan mengapa konsumen memilih produk organik, yaitu bebas bahan kimia; lebih banyak nutrisi (tanaman yang tumbuh dengan organik kaya akan nutrisi, vitamin, mineral, mikronutrien dan enzim, daripada tanaman konvensional); rasanya lebih sedap (kandungan gizi yang tinggi membuat sayur atau buah organik terasa lebih enak); menjaga kelestarian lingkungan dan mengurangi polusi; bebas obat, hormon dan antibiotik (penelitian di Amerika Serikat menemukan bahwa 90\% pestisida ditemukan dalam jaringan lemak daging, telur ikan dan uggas, antibiotik, obat dan hormon pertumbuhan juga sering dipakai dalam pangan ternak (Parlyna dan Munawaroh 2011).

Kalangan konsumen di negara-negara maju sudah menganggap bahwa produk pertanian organik lebih superior baik dalam hal gizi, keamanan maupun kesehatannya. Perilaku tersebut telah meluas ke negara-negara berkembang termasuk Indonesia terutama masyarakat kota. Mengenali perilaku konsumen tidaklah mudah, terkadang terus terang menyatakan kebutuhan dan keinginannya, namun sering pula mereka bertindak sebaliknya. Oleh karena itu, perlunya analisis persepsi nilai, kepedulian keamanan pangan dan kesadaran kesehatan yang memengaruhi kenginan membeli produk, khususnya produk pangan organik.

Berdasarkan uraian tersebut, maka kajian mengenai persepsi nilai, kepedulian keamanan pangan dan kesadaran kesehatan yang memengaruhi keinginan untuk membeli pangan organik, khususnya pada sivitas Institut Pertanian Bogor (IPB) jenjang strata 1 menarik untuk ditelaah lebih lanjut. IPB sebagai perguruan negeri tinggi di nilai potensial dalam mengembangkan pangan organik dan memiliki kepedulian akan hidup sehat, maka dijadikan tempat untuk mengevaluasi persepsi nilai, kepedulian keamanan pangan dan kesadaran kesehatan yang memengaruhi keinginan membeli pangan organik.

\section{Metode Penelitian}

Penelitian ini difokuskan pada persepsi nilai, kepedulian keamanan pangan dan kesadaran kesehatan yang memengaruhi keinginan untuk membeli pangan organik oleh sivitas Institut Pertanian Bogor (IPB) jenjang strata 1 (Sarjana) tanpa membedabedakan bentuk program penyelenggarannya.

Data yang digunakan adalah data primer dan sekunder. Populasi yang digunakan adalah 17.500 mahasiswa aktif strata 1 Institut Pertanian Bogor (IPB). Dalam penelitian ini, digunakan teknik penentuan jumlah contoh dengan Teknik Slovin. yaitu: 


$$
n=\frac{\mathrm{N}}{1+\mathrm{Ne}^{2}}
$$

Keterangan :

$n=$ Jumlah contoh

$\mathrm{N}=$ Jumlah keseluruhan populasi

e = Galat (error) yang dikehendaki

Maka diperoleh jumlah contoh atau responden sebanyak :

$$
n=\frac{17.500}{1+(17.500)(0,1)^{2}}=99,43 \approx 100
$$

Contoh adalah bagian atau sejumlah cuplikan tertentu yang dapat diambil dari suatu populasi dan ditelaah secara rinci. Contoh dapat dikatakan miniatur dari populasi (Sujarweni 2014). Subset ini diambil karena dalam banyak kasus tidak mungkin diteliti seluruh anggota populasi, oleh karena itu dibentuk sebuah perwakilan populasi yang disebut contoh (Ferdinand 2006). Metode penarikan contoh yang digunakan adalah quota sampling, yaitu metode penetapan contoh dengan menentukan kuota terlebih dahulu pada masing-masing kelompok. Dalam hal ini jumlah contoh yang harus di ambil tiap fakultas seperti pada Tabel 1.

Tabel 1. Jumlah contoh tiap fakultas dengan metode kuota

\begin{tabular}{lllccc}
\hline No & Kode & Fakultas & Jumlah Mahasiswa & Proporsi & Jumlah Contoh \\
\hline 1 & A & Pertanian & 1.968 & 0,112 & 12 \\
2 & B & Kedokteran Hewan & 811 & 0,046 & 5 \\
3 & C & Perikanan dan Ilmu Kelautan & 1.784 & 0,101 & 10 \\
4 & D & Peternakan & 877 & 0,050 & 5 \\
5 & E & Kehutanan & 1.661 & 0,094 & 9 \\
6 & F & Teknologi Pertanian & 1.868 & 0,106 & 11 \\
7 & G & Matematika dan IPA & 3.388 & 0,193 & 19 \\
8 & H & Ekonomi dan Manajemen & 3.476 & 0,198 & 20 \\
9 & I & Ekologi Manusia & 1.667 & 0,095 & 9 \\
\hline Jumlah & & 17.500 & 1,00 & 100 \\
\hline
\end{tabular}

Sumber: Direktorat Administrasi Pendidikan IPB 2015 (kemudian diolah)

Alat analisis data yang digunakan adalah regresi linear berganda. Analisis regresi linear berganda digunakan untuk mengetahui pengaruh antara dua atau lebih peubah independen dengan satu peubah dependen (Priyatno 2012). Sebelum melakukan analisis tersebut, dilakukan analisis pendahuluan yaitu uji instrumen pengumpulan data (validitas dan reliabilitas) dan uji asumsi klasik. Selanjutnya dilakukan analisis regresi, uji $t$ dan uji $\mathrm{F}$. Uji $\mathrm{F}$ digunakan untuk melihat pengaruh peubah bebas (independen) secara keseluruhan dan bersama-sama terhadap peubah terikat (dependen). Uji ini disebut uji koefisien regresi secara simultan. Uji t digunakan untuk melihat apakah peubah independen secara individu memiliki pengaruh nyata terhadap peubah terikat. Uji ini disebut uji koefisien regresi secara parsial. Secara matematik persamaan regresi liniar berganda dalam penelitian ini adalah:

$\hat{Y}=a+b_{1} X_{1}+b_{2} X_{2}+b_{3} X_{3}+e$ 
Keterangan :

$\widehat{Y}=$ peubah dependen yang diprediksi (keinginan membeli pangan organik)

$\mathrm{X}_{1}=$ peubah dependen (persepsi nilai)

$\mathrm{X}_{2}=$ peubah dependen (kepedulian keamanan pangan)

$X_{3}=$ peubah dependen (kesadaran kesehatan)

$\mathrm{a}=$ nilai konstanta

$b_{1}=$ koefisien regresi persepsi

$b_{2}=$ koefisien regresi kepedulian

$\mathrm{b}_{3}=$ koefisien regresi kesadaran

$\mathrm{e}=$ galat

\section{Hasil dan Pembahasan}

III.1. Hasil Uji Validitas dan Reliabilitas

Untuk menentukan apakah suatu pertanyaan (item) layak digunakan atau tidak, dilakukan uji validitas metode Korelasi Pearson. Analisis ini dilakukan dengan cara mengorelasikan masing-masing skor item dengan skor total tanpa melakukan korelasi terhadap Spurious Overlap (nilai koefisien korelasi overestimasi). Skor total item adalah penjumlahan dari keseluruhan item (Priyatno 2012). Kriterianya adalah jika $r$ hitung $>r$ tabel, maka dikatakan valid. Sebaliknya, jika $r$ hitung $<r$ tabel, maka dikatakan tidak valid. Nilai $r$ tabel di cari pada taraf nyata 0,05 dengan uji 2 sisi dan jumlah data $(n)=$ 30 atau $\mathrm{df}=28$, maka di dapat $r$ tabel 0,361. Perbandingan $r$ tabel dengan $r$ hitung dapat dilihat pada Tabel 2.

Tabel 2. Hasil uji validitas semua peubah

\begin{tabular}{|c|c|c|c|c|c|}
\hline No & Peubah & $\begin{array}{c}\text { Pertanyaan } \\
\text { (item) }\end{array}$ & $\begin{array}{c}\text { r hitung } \\
\text { (korelasi pearson) }\end{array}$ & $r$ tabel & keterangan \\
\hline \multirow{5}{*}{1} & \multirow{5}{*}{ Keinginan membeli } & 1 & 0,486 & & \\
\hline & & 2 & 0,707 & & \\
\hline & & 3 & 0,791 & & \\
\hline & & 4 & 0,754 & & \\
\hline & & 5 & 0,867 & & \\
\hline \multirow{5}{*}{2} & \multirow{5}{*}{ Persepsi nilai } & 1 & 0,697 & & \\
\hline & & 2 & 0,855 & & \\
\hline & & 3 & 0,608 & & \\
\hline & & 4 & 0,538 & 0,361 & VALID \\
\hline & & 5 & 0,750 & & \\
\hline \multirow[t]{4}{*}{3} & Kepedulian & 1 & 0,560 & & \\
\hline & keamanan pangan & 2 & 0,890 & & \\
\hline & & 3 & 0,787 & & \\
\hline & & 4 & 0,569 & & \\
\hline \multirow{5}{*}{4} & & 1 & 0,514 & & \\
\hline & Kesadaran & 2 & 0,857 & & \\
\hline & kesehatan & 3 & 0,697 & & \\
\hline & & 4 & 0,798 & & \\
\hline & & 5 & 0,650 & & \\
\hline
\end{tabular}


Tabel 2 menunjukkan semua pertanyaan (item) dari tiap peubah memiliki nilai $r$ hitung lebih besar dari $r$ tabel, sehingga semua pertanyaan dalam kuesioner valid dan layak untuk digunakan pada penelitian ini. Di sisi lain, suatu alat ukur dikatakan reliabel bila dalam mengukur suatu gejala pada waktu berlainan senantiasa menunjukkan hasil sama. Jadi alat yang reliabel secara konsisten mampu memberi hasil ukuran sama. Metode uji reliabilitas yang digunakan adalah Cronbach's Alpha, dengan kriterianya jika Cronbach's Alpha <0,6, dikatakan reliabilitas buruk. Jika Cronbach's Alpha 0,6 0,79, dikatakan reliabilitas diterima. Sedangkan jika Cronbach's Alpha $>0,8$, dikatakan reliabilitas baik. Nilai Cronbach's Alpha yang diperoleh dari semua peubah disajikan pada Tabel 3.

Tabel 3. Hasil uji reliabilitas semua peubah

\begin{tabular}{|c|c|c|c|}
\hline No & Peubah & Nilai Cronbach's Alpha & Keterangan \\
\hline 1 & Keinginan membeli & 0,770 & RELIABEL \\
\hline 2 & Persepsi nilai & 0,733 & RELIABEL \\
\hline 3 & Kepedulian keamanan pangan & 0,651 & RELIABEL \\
\hline 4 & Kesadaran kesehatan & 0,711 & RELIABEL \\
\hline
\end{tabular}

Berdasarkan Tabel 5, diketahui semua pertanyaan (item) dari tiap peubah memiliki nilai Cronbach's Alpha di atas 0,6, sehingga semua pertanyaan dalam kuesioner reliabel dan di anggap konsisten, serta relevan terhadap peubah keinginan membeli, persepsi nilai, kepedulian keamanan pangan dan kesadaran kesehatan.

\section{III.2. Analisis Deskriptif Karakteristik Konsumen}

Demografis responden mencakup usia, jenis kelamin, daerah asal, pengeluaran per bulan, status pernikahan, pendidikan terakhir, tempat tinggal dan status pekerjaan. Unsur-unsur demografis tersebut dipilih untuk mengetahui kaitan antara usia, jenis kelamin, daerah asal, pengeluaran per bulan, status pernikahan, pendidikan terakhir, tempat tinggal dan status pekerjaan dengan keinginan membeli pangan organik. Dalam hal ini, pengetahuan terhadap pangan organik dipengaruhi oleh usia, jenis kelamin, daerah asal, pengeluaran per bulan, status pernikahan, pendidikan terakhir, tempat tinggal dan status pekerjaan yang membuat niat tidaknya membeli pangan organik.

Usia responden 98\% adalah 17-24 tahun. Hal ini menunjukan usia merupakan usia yang mengikuti perkembangan teknologi, melalui media masa elektronik, iklan, gadget, online shop dan media sosial. Jenis kelamin responden didominasi oleh wanita 63\%. Di sisi lain, 60\% responden berasal dari luar Jakarta, Bogor, Depok, Tangerang dan Bekasi (JABODETABEK). Hal ini menunjukkan bahwa pemasaran dan informasi tentang manfaat pangan organik tidak hanya ada di JABODETABEK, namun juga populer diluar JABODETABEK. Pengeluaran per bulan responden 52\% berkisar Rp1 jt - 2 jt. Hal ini wajar, mengingat biaya kebutuhan hidup sehari-hari meningkat pasca kenaikan BBM. Status pernikahan responden $98 \%$ belum menikah. Namun ada $2 \%$ responden yang sudah menikah dan belum memiliki anak. Pendidikan terakhir responden 60\% SMA, mayoritas tinggal di Kabupaten Bogor dan 60\% tidak bekerja.

Pada analisis deskriptif statistik, keinginan membeli memiliki nilai rataan 4,56 dan simpangan baku 0,466; persepsi nilai diperoleh nilai rataan 4,61 dan simpangan baku 0,415 ; kepedulian keamanan pangan diperoleh nilai rataan 4,67 dan simpangan 
baku 0,39; kesadaran kesehatan diperoleh nilai rataan minimum 3,20, nilai rataan 4,79 dan simpangan baku 0,322. Hal ini menunjukkan semua peubah yang diteliti direspon baik (rataan 4,56-4,79) atau konsumen yang merupakan responden mahasiswa IPB dapat menerima keberadaan pangan organic sebagai bahan yang dikonsumsi dalam kehidupan sehari-hari.

\section{III.3. Hasil Uji Asumsi Klasik}

Uji asumsi klasik regresi merupakan uji prasyarat ketika menggunakan analisis regresi linear berganda, yaitu meliputi uji normalitas, uji multikolinearitas dan uji heteroskedastisitas. Jika asumsi tersebut dilanggar, misal model regresi tidak normal, terjadi multikolinearitas atau heteroskedastisitas, maka dipastikan hasil analisis regresi dan pengujian seperti uji t dan F menjadi tidak valid atau bias (Priyatno 2012).

Uji multikolinearitas diperlukan untuk mengetahui ada tidaknya peubah independen yang memiliki kemiripan dengan peubah independen lainnya dalam suatu model (Sujarweni, 2014). Model regresi yang baik tidak terjadi korelasi antara peubah independen dengan peubah independen lainnya. Kriteria tidak terjadi multikolinearitas adalah jika nilai Variance Inflation Factor (VIF) yang diperoleh berada di kisaran 1-10 serta nilai tolerance yang diperoleh lebih dari 0,1. Berdasarkan hasil uji multikolinearitas yang telah dilakukan, persepsi nilai dengan VIF 1,199 dan tolerance 0,834; kepedulian keamanan pangan dengan nilai VIF 1,692 dan tolerance 0,591; dan kesadaran kesehatan dengan nilai VIF 1,534 dan tolerance 0,652. Hasil tersebut menunjukkan model regresi tidak mempunyai masalah multikolinearitas.

Heteroskedastisitas adalah keadaan dimana terjadi ketidaksamaan ragam dari suatu residual untuk semua pengamatan pada model regresi. Model regresi yang baik tidak terjadi masalah heteroskedastisitas (Priyatno, 2012) yang diuji dengan metode Spearman's Rho Testing. Dikatakan tidak terjadi heteroskedastisitas, jika taraf nyata yang diperoleh peubah independen dengan residual lebih dari 0,05. Berdasarkan hasil uji heteroskedastisitas, diketahui bahwa korelasi persepsi dengan unstandardized residual memperoleh taraf nyata 0,160; korelasi kepedulian keamanan pangan dengan unstandardized residual memperoleh taraf nyata 0,658; dan korelasi kesadaran kesehatan dengan unstandardized residual memperoleh taraf nyata 0,863 . Mengacu hasil taraf nyata tersebut, disimpulkan model regresi tidak mempunyai masalah heteroskedastisitas.

Uji normalitas digunakan untuk menguji apakah data residual terdistribusi secara normal atau tidak. Residual merupakan nilai sisa atau selisih antara nilai peubah dependen dengan peubah dependen pada analisis regresi. Model regresi yang baik memiliki data residual terdistribusi secara normal (Priyatno 2012). Jika asumsi normalitas tidak terpenuhi dan penyimpangan normalitas terlalu besar, maka berakibat bias pada hasil uji statistik (Ghozali 2005). Dua cara yang sering digunakan untuk menguji normalitas residual melalui dengan analisis grafik (normal P-P plot) regresi dan uji One Sample Kolmogorov-Smirnov. Dari grafik hasil uji normalitas dengan grafik normal P-P plot diketahui titik-titik menyebar sekitar garis dan mengikuti garis diagonal, maka residual pada model regresi tersebut terdistribusi normal. Jika menggunakan uji One Sample Kolmogorov-Smirnov diperoleh taraf nyata (Asym.Sig 2tailed) 0,053, dimana taraf nyata lebih dari 0,05, maka residual terdistribusi normal. 
III.4. Persepsi Nilai, Kepedulian Keamanan Pangan dan Kesadaran Kesehatan yang Memengaruhi Keinginan Membeli Pangan Organik Secara Simultan

Hasil Uji F membuktikan terdapat pengaruh tingkat kesadaran tentang kesehatan, persepsi nilai dan kepedulian keamanan pangan terhadap keinginan membeli produk pangan organik secara bersama-sama. Dengan menggunakan tingkat kepercayaan $95 \%, \alpha=5 \%$, nilai df 1 diperoleh dari jumlah peubah-1 atau 4-1=3. Sedangkan nilai df 2 diperoleh dari $n-k-1$, di mana $n$ adalah jumlah data dan $\mathrm{k}$ jumlah peubah independen, sehingga hasilnya adalah 100-3-1=96, yaitu nilai $F$ tabel 2,699 (Tabel 4).

Tabel 4. Hasil Uji F

\begin{tabular}{lccccc}
\hline & \multicolumn{5}{c}{ Anova } \\
Sum of Squares & df & Mean Square & F & Sig. \\
\hline Regression & 7.140 & 3 & 2.380 & 15.888 & 0.000 \\
Residual & 14.380 & 96 & 0.150 & & \\
Total & 21.520 & 99 & & & \\
\hline
\end{tabular}

Berdasarkan Tabel 4, diperoleh nilai F hitung 15,888, dimana F hitung $(15,888)>$ F tabel $(2,699)$, artinya persepsi nilai, kepedulian keamanan pangan dan kesadaran kesehatan secara bersamaan mampu membangun persepsi baik di benak konsumen dan memengaruhi konsumen untuk membeli pangan organik dalam arti umum.

III.5. Persepsi Nilai, Kepedulian Keamanan Pangan dan Kesadaran Kesehatan yang Memengaruhi Keinginan Membeli Pangan Organik Secara Parsial

Persepsi nilai, kepedulian keamanan pangan dan kesadaran kesehatan memiliki pengaruh berbeda-beda terhadap keinginan membeli pangan organik. Hal itu didukung oleh besarnya nilai koefisien masing-masing peubah independen yang mempengaruhi peubah dependen (Tabel 5).

Tabel 5. Hasil Uji t

\begin{tabular}{lccccc}
\hline Variabel & Koefisien & Std. Error & t hitung & Prob & R-square \\
\hline (Constant) & 0.1570 & 0.6479 & 0.2424 & 0.8090 & \\
Persepsi nilai & 0.2773 & 0.1025 & 2.7066 & 0.0080 & $33.2 \%$ \\
Kepedulian keamanan pangan & 0.2276 & 0.1296 & 1.7565 & 0.0822 & \\
Kesadaran kesehatan & 0.4300 & 0.1492 & 2.8808 & 0.0049 & \\
\hline
\end{tabular}

Persepsi nilai secara parsial berpengaruh terhadap keinginan membeli produk pangan organik pada umumnya, karena nilai t hitung 2,706, di mana tabel distribusi $t$ pada $\alpha=5 \%: 2=2,5 \%$ (uji dua sisi) pada derajat bebas (df) n-k-1 atau 100-3-1 = 96 ( $n$ adalah jumlah data dan $\mathrm{k}$ adalah jumlah peubah independen). Dengan pengujian dua sisi (taraf nyata $=0,025$ ), hasil diperoleh untuk t tabel $+1,985$ atau $-1,985$. Nilai t hitung $(2,706)>t$ tabel $(1,985)$. Besar koefisien 0.2773 , artinya terdapat pengaruh nyata dan positif persepsi nilai responden terhadap keinginan membeli produk pangan organik pada umumnya. Kondisi tersebut disebabkan konsumen sangat mempertimbangkan nilai (value), ketika mengkonsumsi pangan organik, khususnya terkait kesehatan. Dengan kata lain semakin baik persepsi responden terhadap nilai pada pangan organik, maka semakin meningkatkan keinginan membeli pangan organik. 
Kepedulian pada kemanan pangan secara parsial tidak berpengaruh terhadap keinginan membeli produk pangan organik, karena nilai t hitung 1,756, di mana tabel distribusi t pada $\alpha=5 \%: 2=2,5 \%$ (uji dua sisi) pada derajat bebas (df) $n-k-1$ atau 100 3-1 = 96 ( $n$ adalah jumlah data dan $\mathrm{k}$ adalah jumlah peubah independen). Dengan pengujian dua sisi (taraf nyata $=0,025$ ), hasil diperoleh untuk $t$ tabel $+1,985$ atau 1,985 . Nilai $t$ hitung $(1,756)<t$ tabel $(1,985)$, artinya tidak terdapat pengaruh kepedulian keamanan pangan terhadap keinginan membeli produk pangan organik pada umumnya, karena dalam membeli produk pangan, tidak semua konsumen beranggapan keamanan pangan itu penting. Misalnya konsumen beranggapan bahwa produk pangan yang mahal sudah pasti aman dan bermutu, padahal belum tentu demikian. Contohnya makanan cepat saji (fast food) atau makanan sampah (junk food) berharga mahal, tetapi sebenarnya belum tentu aman dari sisi kebersihan.

Kesadaran kesehatan secara parsial berpengaruh terhadap keinginan membeli produk pangan organik karena nilai nilai t hitung 2,880 , di mana tabel distribusi t di cari dengan $\alpha=5 \%: 2=2,5 \%$ (uji dua sisi) pada derajat bebas (df) n-k-1 atau 100-3-1 = 96 ( $n$ adalah jumlah data dan $\mathrm{k}$ adalah jumlah peubah independen). Dengan pengujian dua sisi (taraf nyata $=0,025$ ), hasil diperoleh untuk t tabel $+1,985$ atau $-1,985$. Nilai $t$ hitung $(2,880)>t$ tabel $(1,985)$, artinya terdapat pengaruh tingkat kesadaran tentang kesehatan terhadap keinginan membeli produk pangan organik pada umumnya. Besar koefisien 0.430 menunjukkan pengaruh positif kesadaran kesehatan responden terhadap keinginan membeli produk pangan organik pada umumnya. Konsumen mengerti bahwa pangan organik baik bagi kesehatan. Sebagai produk pangan yang alami dan diproduksi tanpa bahan kimia maupun pestisida, pangan organik diproduksi dengan sesedikit mungkin atau bebas sama sekali dari unsur-unsur kimia berupa pupuk, pestisida, hormon, dan obat-obatan. Bahan pangan organik hanya menggunakan bibit lokal dan hanya menggunakan pupuk yang berasal dari alam berupa kotoran hewan dan kompos, sehingga alami dan baik bagi kesehatan tubuh.

Analisis regresi linear berganda digunakan untuk menganalisis pengaruh dua atau lebih peubah independen dengan satu peubah dependen, yaitu memprediksi nilai dari peubah dependen yang disebabkan oleh naik turunnya nilai peubah independen. Selain itu, analisis ini mengevaluasi arah hubungan peubah independen dengan peubah dependen, apakah berhubungan positif atau negatif (Priyatno 2012).

Setelah dilakukan pengujian, diperoleh nilai konstanta 0,157 . Koefisien regresi persepsi nilai 0,277; koefisien regresi kepedulian keamanan pangan 0,228; koefisien regresi kesadaran kesehatan 0,430, maka persamaannya sebagai berikut:

$\widehat{Y}=0,157+0,277 X_{1}+0,228 X_{2}+0,430 X_{3}$

Keterangan:

$\widehat{Y}=$ peubah dependen yang diprediksi (keinginan membeli pangan organik)

$X_{1}=$ peubah dependen (persepsi nilai)

$\mathrm{X}_{2}=$ peubah dependen (kepedulian keamanan pangan)

$X_{3}=$ peubah dependen (kesadaran kesehatan)

Nilai konstanta 0.1570 menunjukkan jika perspesi nilai, kepedulian dan kesadaran kesehatan konsumen terhadap pangan organik bernilai 0 , maka keinginan 
membeli pangan organik konsumen bernilai 0.1570 (intersep). Dengan kata lain, apabila peubah persepsi nilai, kepedulian keamanan pangan dan kesadaran kesehatan tidak memberikan kontribusi terhadap peubah keinginan membeli pangan organik pada umumnya, maka secara rataan nilai dari peubah keinginan membeli pangan organik akan sebesar intersep tersebut. Jika persepsi konsumen terhadap pangan organik mengalami naik satu satuan, maka keinginan membeli pangan organik konsumen mengalami peningkatan 0,277 satuan, dengan asumsi peubah independen lainnya tetap. Bila kepedulian konsumen terhadap keamanan pangan mengalami naik satu satuan, maka keinginan membeli pangan organik konsumen mengalami pengingkatan 0,228 satuan dengan asumsi peubah independen lainnya tetap; atau jika kesadaran akan kesehatan konsumen mengalami naik satu satuan, maka keinginan membeli pangan organik pada umumnya oleh konsumen mengalami pengingkatan 0,430 satuan, dengan asumsi peubah independen lainnya tetap.

Selain itu, dilakukan analisis koefisien determinasi (adjusted $R^{2}$ ) untuk melihat kontribusi pengaruh peubah independen secara bersama-sama terhadap peubah dependen. Hasil menunjukkan nilai $R^{2} 0,332$ (33,2\%), berarti kontribusi peubah independen (persepsi nilai, kepedulian keamanan pangan dan kesadaran kesehatan) terhadap peubah dependen (keinginan membeli pangan organik) 33,2\% dan sisanya $(66,8 \%)$ dipengaruhi oleh peubah lain yang tidak diteliti pada penelitian ini.

\section{Kesimpulan}

Dari hasil deskriptif didapatkan usia mayoritas 17-24 tahun, jenis kelamin didominasi wanita dan berasal dari luar JABODETABEK, pengeluaran per bulan Rp1.000.000,00-2.000.000,00 dan mayoritas belum menikah. Hasil analisis statistik menunjukkan pengaruh nyata dan positif persepsi, dan kesadaran kesehatan terhadap keinginan membeli produk pangan organik pada umumnya, disamping pengaruh nyata dan positif tingkat kesadaran tentang kesehatan, persepsi nilai dan kepedulian keamanan pangan secara bersama-sama terhadap keinginan membeli produk pangan organik. Disisi lain tidak terdapat pengaruh nyata dan positif kepedulian pada keamanan pangan terhadap keinginan membeli produk pangan organik.

\section{Daftar Pustaka}

Alamsyah I. 2010. Analisis Perilaku Konsumen Dalam Keputusan Pembelian Sayuran Organik di Giant Yasmin Bogor. [Skripsi]. Bogor (ID): Institut Pertanian Bogor.

Ferdinand A. 2006. Metode Penelitian Manajemen. Semarang (ID): Badan Penerbit Universitas Diponegoro.

Ghozali I. 2005. Aplikasi Analisis Multivariate dengan Program SPSS. Semarang (ID): Badan Penerbit Universitas Diponegoro.

Hubeis M, Najib M, Widyastuti H, Wijaya NH. 2013. Strategi Produksi Pangan Organik Bernilai Tambah Tinggi yang Berbasis Petani. Jurnal Ilmu Pertanian Indonesia (JIPI), 18(3): 194-199.

[IPB] Direktorat Administrasi Pendidikan Institut Pertanian Bogor. 2015. Jumlah Mahasiswa Aktif 2015. Bogor (ID): IPB. 
Parlyna R, Munawaroh. 2011. Konsumsi Pangan organik Meningkatkan Kesehatan Konsumen? Jurnal EconoSains. 9(2): 157-165.

Priyatno D. 2012. Mandiri Belajar Analisis Data dengan SPSS. Yogyakarta (ID): Mediakom.

Sujarweni VW. 2014. SPSS untuk Penelitian. Yogyakarta (ID): Pustaka Baru Press.

Thio S, Harianto NYS, Sosiawan RF. 2008. Persepsi Konsumen Terhadap Pangan organik di Surabaya. Jurnal Manajemen Perhotelan Universitas Kristen Petra, 4(1): 18-27.

Wijaya T. 2013. Anteseden Perilaku Beli Produk Ramah Lingkungan: Studi Perilaku Konsumen Makanan Organik. Jurnal Ekonomi dan Bisnis. 7 (3): 149-161.

[YLKI] Yayasan Lembaga Konsumen Indonesia. 2012. Survei Konsumen Organik Indonesia. [Internet]. [Diunduh 14 Okt 2015] Tersedia pada http:// www.organicindonesia.org/05infodatanews. php?id=443. 